\title{
NURSING INFORMATICS: UNVEILING THE COMPUTER USE BY NURSES
}

\author{
Laura Misue Matsudaํ, Yolanda Dora Martinez Évora², Ieda Harumi Higarashi³, Carmen Silvia Gabriel', \\ Kelly Cristina Inoue
}

${ }^{1}$ Ph.D. in Fundamental Nursing, Professor at the Nursing Graduate Program of the Universidade Estadual de Maringá (UEM). Maringá, Paraná, Brazil. E-mail: lmmatsuda@uem.br

${ }^{2}$ Ph.D. in Inter-unit Nursing. Full professor at the Escola de Enfermagem de Ribeirão Preto (EERP) da Universidade de São Paulo (USP). Ribeirão Preto, São Paulo, Brazil. E-mail: yolanda@eerp.usp.br

${ }^{3}$ Ph.D. in Education. Professor at the Nursing Graduate Program of UEM. Maringá, Paraná, Brazil. E-mail: ihhigarashi@uem.br

${ }^{4}$ Ph.D. in Fundamental Nursing. Professor at the EERP/USP. Ribeirão Preto, São Paulo, Brazil. E-mail: cgabriel@eerp.usp.br

${ }^{5}$ Doctoral student in Nursing. Professor at Faculdade Ingá and intensive care nurse at the University Hospital of Maringá. Maringá, Paraná, Brazil. E-mail: kellyelais@hotmail.com

\begin{abstract}
Study conducted with the objective of understanding the assistant nurses' perception of a philanthropic institution about the computer use at work. The data collection happened in January 2013, through interviews with 12 nurses who answered the question: tell me about the computer use at your work. The data were treated using the content analysis technique, in which emerged the following theme categories and subthemes: Realizing positive aspects on computer use (nine subthemes); Realizing negative aspects on computer use (four subthemes); Suggesting actions to improve computer use (six subthemes); and Evaluating the computerization at work (three sub-themes). It was possible to conclude that the nurses have the perception that the computer use is related to the easily; the agility and practicality in development of professional activities; but there are technical and operational aspects that still need to be improved.
\end{abstract} DESCRIPTORS: Computers. Nurses. Medical informatics.

\section{INFORMÁTICA EM ENFERMAGEM: DESVELANDO O USO DO COMPUTADOR POR ENFERMEIROS}

RESUMO: Estudo realizado com o objetivo de apreender a percepção de enfermeiros assistenciais, de uma instituição filantrópica, sobre o uso do computador no trabalho. A coleta dos dados ocorreu em janeiro de 2013, a partir de entrevistas com 12 enfermeiros, que responderam à questão: fale-me sobre o uso do computador no seu trabalho. Os dados foram tratados utilizando a técnica análise de conteúdo, por meio da qual emergiram as seguintes categorias temáticas e subtemas: Percebendo aspectos positivos no uso do computador (nove subtemas); Percebendo aspectos negativos no uso do computador (quatro subtemas); Sugerindo ações para melhorar o uso do computador (seis subtemas); e Avaliando a informatização no trabalho (três subtemas). Foi possível concluir que os enfermeiros têm a percepção de que o uso do computador se relaciona com a facilidade, a agilidade e a praticidade no desenvolvimento das atividades profissionais, mas ainda existem aspectos técnicos e operacionais que precisam ser melhorados.

DESCRITORES: Computadores. Enfermeiros. Informática médica.

\section{INFORMÁTICA APLICADA A LA ENFERMERÍA: DESVELANDO EL USO DEL COMPUTADOR POR ENFERMEROS}

\begin{abstract}
RESUMEN: Estudio realizado con el objetivo de comprender la percepción de enfermeros asistenciales, de una institución filantrópica, acerca del uso del computador en el trabajo. La recolección de datos ocurrió en enero de 2013, a partir de entrevistas con 12 enfermeros que respondieron a la pregunta: hábleme sobre el uso del computador en su trabajo. Los datos fueron tratados utilizando la técnica análisis de contenido, por medio del cual emergieron las siguientes categorías temáticas y subtemas: Percibiendo aspectos positivos en el uso del computador (nueve subtemas); Percibiendo aspectos negativos en el uso del computador (cuatro subtemas); Sugiriendo acciones para mejorar el uso del computador (seis subtemas); y Evaluando la informatización en el trabajo (tres subtemas). Fue posible concluir que los enfermeros tienen la percepción de que el uso del computador se relaciona con la facilidad, la agilidad y la practicidad en el desarrollo de las actividades profesionales; pero aún existen aspectos técnicos y operacionales que necesitan ser mejorados.

DESCRIPTORES: Computadores. Enfermeros. Informática médica.
\end{abstract}




\section{INTRODUCTION}

Given its quick storage and processing of a large amount of data, the computer has been increasingly frequent and necessary in the health field. As a result, Information Technology (IT), when applied in various manners, such as storage, recovery and optimization of information, as well as in the solution of healthcare problems, is known as health informatics. ${ }^{1}$

The increased use of IT by healthcare services has required the acquisition of knowledge on the efficient use of IT tools by health professionals, as well as its integration into daily practice. ${ }^{2}$ On the other hand, the use of IT in healthcare services gives the opportunity to identify and eliminate inefficient practices, by providing essential and complete information, in a more agile manner than the manual record system. ${ }^{3}$

With the use of IT in health care, electronic records can be structured from a basic data summary in order to create systems that are based on the best evidence and that support clinical decision, which can contribute for patients' quality of life and safety and speed up decision-making, thus harmonizing actions. ${ }^{4}$

In the field of nursing, the preliminary results of a mixed method study, conducted in a Canadian hospital, showed that the use of IT, by means of palmtops, improved quality of life at work and of care of patients, also making it possible to use scientific evidence in care practice. ${ }^{5}$ On the other hand, negative aspects of IT were reported, including lack of training, resistance from nurses and the perception that the time spent recording data does not decrease. ${ }^{6}$

Although there are studies focused on computer use for teaching and nursing practice, ${ }^{2-7}$ recent publications which assess the perception of nurses on computer use are not usually found. This is probably due to the fact that this step has already been taken in developed countries, as opposed to Brazil. ${ }^{1}$

A study with the aim to evaluate the global impact of Electronic Records on Health (RES, as per its acronym in Portuguese) ${ }^{8}$ showed the results of publications that pointed out to the positive effects of this type of record in care process, however highlighting the absence of concrete evidence that RES foster care efficiency.
Despite the limitations to obtain the different resources that compose the necessary material such as computers, software and human resources at all levels - in order to use computers in Brazilian health institutions systematically, it is possible to observe that the use of this feature is important and necessary.

Considering that the perception of nurses who use computers at work can foster decisionmaking related to the implementation, use and monitoring of this technology, this study had the following guiding question: what is the perception of nurses on computer use at work? To answer it, the aim of the present investigation was to unveil the perception of nurses on computer use at work.

\section{METHOD}

This is a qualitative, descriptive and exploratory study, conducted in a philanthropic hospital in the countryside of the state of Paraná, Brazil, where computer-based systems were implemented for nursing care about 10 years ago. In the aforementioned institution, 68 nurses provided direct care and remained full-time in the unit or during most of the day. Of these nurses, 12 participated in this study, and the selection was made by means of a list provided by the Nursing Management, and participants with at least six months of service were randomly selected and interviewed. The number of interviews was determined by the researcher's perception on whether the established goals were achieved.

Data collection was performed in January 2013 by means of semi-structured interviews, of an average 15-minute length, and guided by the following question: 'tell me about computer use at work'. In addition, other questions were necessary for some interviews: 'talk about the importance of computer use for care services'; 'do you have difficulties in using the computer?'; 'in what aspects? ; what are your suggestions for improving computer use at work?'

The interviews were previously scheduled and conducted during work shift within the hospital, in a private room. Audio resources were used (two digital recorders) as well as notes taken in a diary throughout the interviews. These notes referred to the researcher's perception on the situation, the environment and the interviewee during the interview. 
The audio recordings were fully transcribed and subsequently proofread, so as not to alter the content expressed by the subjects, and notes were eventually added. The use of notes aimed to better understand the statements, by capturing nonverbal elements of communication and including pauses, facial expressions and gestures considered relevant for unveiling the reality narrated by the interviewees. Therefore, these observations were interpolated to interviews and included in the statements between brackets - when they referred to words occasionally omitted in the speech -, and between square brackets - when expressing pauses in the speech.

Data were processed and analyzed by the content analysis technique, ${ }^{9}$ in the form of theme analysis, implementing the pre-analysis, exploration and processing phases, results processing, inference and interpretation. In the pre-analysis and exploration phases, the transcribed texts were read several times, which included the content of interviews already completed with the respective remarks. This reading, called thorough reading, allowed us to highlight, at the right-hand side margin of the page, text elements to set up the meaning units. In data processing, these elements were grouped according to their similarity in order to create theme categories. In the inference and interpretation phases, the empirical results, already divided into categories, were referred to the relevant bibliography. In the presentation of results, theme categories were represented by quotes/excerpts of statements, and the abbreviation "Nur." (for nurse) was used followed by a number (Nur. 1, Nur. 2...), which indicates the sequence of interviews.

The study was conducted in compliance with ethical and legal requirements in force, and registered under number $73.651 / 2012$ by the $\mathrm{Hu}-$ man Research Ethics Committee (COPEP) of the Universidade Estadual de Maringá.

\section{RESULTS AND DISCUSSION}

Of the 12 participants, eight were female and four were male, aged between 24 and 38 years old; graduated for 2 to 17 years; working in the institution for 1 to 17 years; using computers for at least one year. Most of them $(n=10)$ already had a specialization.
From the selection of relevant speeches, 22 sub-themes appeared and gave rise to the following theme categories: (1) Perception of positive aspects of computer use; (2) Perception of negative aspects of computer use; (3) Suggestion of actions to improve computer use; and (4) Evaluation of computerization at work.

\section{Perception of positive aspects of computer use}

This theme category is based on nine subthemes: Easy access to information; quicker decision-making and care; 24-hour support from the IT Service; safety of information and care; more time available for patients and relatives; fewer displacements within the service; paper and printing savings; data organization; access to patients general information.

Easy access to information with the computer was one of the factors that stood out and was related to quicker decision-making and care, as well as fewer displacements within the service. This is due to the fact that, when forms are filled in manually, the information systems and the way data are transferred and moved require more time and human resources. ${ }^{1}$

The following excerpts confirm this:

[...] ease. For instance: there is a doctor at the emergency room. I call him and say: look doctor, that result was this, or that [...]. He was in another service, the results came out, he saw them on the computer and prescribed the antibiotics from there [...] (Nur. 6).

[...] it improved a lot, I have access to [information on] all patients in the hospital [...]. Before, the doctor did the prescription, we had to enter it in the computer, and then send the medicine from the pharmacy. Now it's all done automatically [...] (Nur. 11).

[...] it's very good, you know. It speeds up the prescription. [...] there is no need for staff to go downstairs and take it [to the pharmacy], or read the prescription or even decipher it [the doctor's handwriting] (Nur. 7).

As we can see from these excerpts, computer use speeds up the care process, as a result of less time spent with displacements of staff between different services. This is important because, in some pathological conditions such as severe sepsis and septic shock, the speed of therapeutic suitability is essential for the patient's survival..$^{10}$ In addition, 
the decreased displacement of staff reduces the transit of persons within the hospital, and this is recommended as a measure of infection control related to health care. ${ }^{11}$

Besides saving time and work, computerization of the process of prescription and distribution of medicine reduces the risk of medication error, which occasionally occurs in hospitals, due to wrong transcription or unreadability of prescriptions, ${ }^{12}$ as reported in the speech below:

I think it prevents some mistakes [...] medication errors, many things [...]. I think it's essential in order to prevent mistakes (Nur. 6).

However, IT can contribute even more to patients' safety. After all, international experiences ${ }^{13-14}$ revealed that tools of support to clinical decision can be added to electronic prescription systems, by helping in the drug dosage, providing alerts on harmful drug interactions, recommendations regarding a deferral in accordance with diet restrictions, and preparation of parenteral solutions and infusion rates, thus optimizing drug therapy.

Another positive aspect of computer use highlighted by nurses was that they have more time available to devote to patients and their relatives, as a result of time saved with information transmission.

[...] so we can save time. We can have more time available for the patient and his relatives, for their visit, for talking with them [...] (Nur. 10).

[...] so, we can prioritize our time with necessary things, such as seeing other patients (Nur. 6).

The statements show that computer use allows for a better and closer care of patients and relatives; as a result, it is possible to improve reception and listening, which are elements that are part of humanized and patient-oriented care. Similar results were found in a study carried out with 34 nurses of ICUs from a general hospital in São Paulo, in which it was observed that computer use resulted in more time available for planning and active participation of professionals in direct care of patients, as time spent with bureaucratic activities and obtaining information was reduced. ${ }^{15}$

Although it is believed that the use of IT results in more time for planning and participation in direct care ${ }^{5,15}$ it is necessary to deepen this topic. In a study carried out in China, ${ }^{16}$ nurses were convinced by the idea that a greater amount of time corresponded to closer and better care of patients.

Computer use was also associated with continuity of care, as it gives access to patients' general information, their past hospitalizations and present; besides, it allows for paper/printing savings, a greater organization and safety of data and care:

[...] [the computer] is important for patient care, for continuity of care. [...] it's very easy to see the patient's evolution. Not like when we have that paper mountain and we have to look up each day to see what has been done. We see everything right away (Nur. 8).

It's more practical. We don't waste time doing manual prescriptions, one, two, three, four sheets. This results in too much paper here [in the service] (Nur. 10).

The electronic storage of patients' data provides more safety to information, and consequently, to care. This is because manual systems require further attention to filing different printed records that make up the patient's medical history, with greater risks of mistakes and loss of documents. A recent study that explored the perceptions of nurses on computer use in hospitals ${ }^{3}$ found that interviewees mentioned the following positive aspects: the possibility of using data at the moment of care, reliability, completeness and accuracy of information.

The completeness and accuracy of information can be influenced by the amount of paper to be analyzed in manual systems, making it difficult to retrieve previous information, which the patient does not always remember or is not in clinical condition to report. In this scenario, computer use tends to facilitate the continuity of care, by preventing unnecessary care or intervention, or even helping in more adequate decision-making.

In the present study, it is possible to observe that the participants expressed themselves in favor and even satisfied with computer use, as positive words appeared in the statements, such as: ease (53 times), agility (13 times) and practicality (11 times).

\section{Perception of negative aspects of computer use}

The four sub-themes that make up this category are related to technical and operational 
aspects, such as: copy of prescriptions and reports; lack of computers in the nursing room; need for portable computers (palmtops, tablets, laptops); and need for training/updating.

Although the interviewees expressed their satisfaction with IT, the number of computers in relation to the number of workers seems to be insufficient. In addition, the use of desktop computers was pointed out as a negative aspect:

We get stuck to the machine. We're not able to be in front of the patient and write it all down at the same time. [...] I have to stop what I'm doing, go to the computer [in the nursing room], sit down and type it all (Nur. 8).

The previous excerpt notes that the difficulty in using desktop computers is due to the distance between the machine and the patient, which requires nurses to move away to take notes, thus preventing them from doing it where care is being provided. ${ }^{1}$ Even if nurses stick to the fact that data accuracy is ensured, by reviewing each patient's observations, using desktop computers is still a problem because of the time wasted in displacements between the nursing room and the patient's bed. In that sense, a possible alternative is the use of palmtops with wireless remote access. ${ }^{5}$

Moreover, it is important to observe that the consolidation of nursing notes takes place at one single moment. Although this does not seem to be a major concern for Nurse 8 , it can result in greater risks of mistakes in information about patients and failure to indicate the exact moment of intervention, which can consequently raise doubts regarding data legitimacy. ${ }^{17}$

Some nurses reported lack of training, which was only given at the time of recruitment:

We had no more trainings. Only at the time of recruitment (Nur. 5).

when we begin to work here, there is a basic training on prescription, in which we see what is needed. Even so, we don't see everything (Nur. 8).

As a justification for periodic training, participants mentioned the occurrence of software and hardware changes over time, besides the persisting difficulty of computer operationalization by older professionals.

The issue of training during working hours is a challenge for healthcare institutions, which have difficulties in making work leave possible for this purpose, due to staff shortage. However, it is necessary to develop internal mechanisms so as nurses are continuously updated and fit for use of all resources offered by computers.

A risky computer feature, which was reported as a negative aspect, is the possibility to copy/paste information. In this way, the copy of prescriptions in full, without assessing a patient and without a proper analysis and reflection on what was previously prescribed, must be countered in order to comply with the Code of Medical Ethics ${ }^{18}$ and the Code of Ethics of Nursing Professionals. ${ }^{19}$ Some excerpts report such conduct and address the issue:

[...] some doctors end up copying, they don't look at [the patient] you know? They end up prescribing a medication that has already been stopped. [...] this copying thing also happens [...] in nursing. We end up not paying attention to things and then we need to do it manually, deleting it (Nur. 12).

[...] we have a copy here, so we can click on a prescription and copy everything. As a nurse, we have to be careful with copying, because sometimes the prescription comes up all wrong [...] (Nur. 6).

Although copying/pasting notes is perceived as something negative by some nurses, others are in favor of this practice, as shown in the statements below:

[...] we grab the previous report, copy all and just edit it. We don't have to write the same thing every day (Nur. 4).

It is important to remember that every nursing professional has the ethical responsibility of entering in the patient's medical record all information that is essential to care, in a complete and reliable manner, in order to ensure the continuity of care, so it is forbidden to record partial or inaccurate information about the care provided. ${ }^{19}$ In this regard, it is recommended that the nursing notes are recorded immediately after each intervention or care provided, with respective times, ${ }^{20}$ which would avoid verbatim copies, with little changes, of nursing reports.

It is seen that the lack of computers and the need for portable devices can be solved by including these items in the institution's budget plan; whilst the need for periodic training requires professional involvement and incentives from the institution for planning and execution. These limitations or difficulties seem easier to solve than the 
copy of prescriptions and reports, which is related to individual conduct and belongs to the ethical and professional context.

\section{Suggestion of actions to improve computer use}

The creation of this theme category was made by gathering the sub-themes: software update; more computers available; portable computers; full copy block; training courses; easy delivery of material and/or medicine by the pharmacy.

The suggestions addressed are coherent with the negative aspects reported by nurses. As it was mentioned previously, they do not seem difficult to solve, as they depend on software adaptation and purchase of equipment.

I think so, including more items [in nursing prescription] (Nur. 8).

[...] software update, every two years, in a more detailed way [...] it would be nice even for employees themselves (Nur. 10).

Given the fast changes in conducts, medicine, equipment and processes, software adaptation in nursing is not an easy task. Even so, information provided by professionals who work with it in their routine is essential to promote usability and system improvement. ${ }^{5}$

In addition to system adaptations, suggestions were made to have more computers available, including portable devices, which would allow for the access and record of data next to the patient.

Maybe increasing the number of computers [...]. I don't know, maybe more comfortable chairs, more ergonomic [...] (Nur. 11).

I think there should be portable computers, like [...] laptops, I don't know, something like that, more modern, so we can be closer to the patient. We can do things with the patient, seeing them (Nur. 11).

The availability of computers is a need that cannot be postponed because despite having been in use for ten years, this can result in frustration and unnecessary stress. As for the suggestion of ergonomic chairs, confirmed by the interviewee's demonstration of bad posture and discomfort, even if it was reported only by one nurse, it is still an important factor for workers' health, because as new software programs are implemented, their operationalization can result in longer periods in sitting position, which is a potential factor for other work-related osteomuscular diseases, as well as the aggravation of common diseases that affect professionals from this field.

Among the ergonomic aspects to be considered for computer use, we can mention the correct posture of nurses, which have to be maintained with the help of swivel chairs, adjustable height, separate seat and back to avoid pain and injuries in the neck, shoulder and lower back. ${ }^{1}$ Notwithstanding the absence of ergonomic chairs in the institution, possibly due to their high costs, this change should be implemented, due to the medium and long-term benefits, as according to the literature, ${ }^{21}$ ergonomic adaptations are always recommended to prevent risks and health impacts.

Other suggestions are related to the need for restraining the copy/paste practice of prescriptions, for staff training on computer use and for facilitating the provision of medication and material in situations of emergency or work overload.

The first two suggestions have been addressed and the possible solutions are:

I think copy/paste should be overcome. CRTL C + CRTL V should be prohibited. Workers should make better use of computers (Nur. 7).

[...] what bothers me is this [prescription] copy thing. [...] maybe if some kind of control could be done to improve this [...]. We can see that it's being copied from the other day, and it keeps going like this! I think more control is necessary! (Nur. 5).

Regarding Nur. 5, when addressing the "copy/paste" issue, he showed some irritation, his sharp tone of voice and fixed gaze showed his disapproval regarding this conduct. Despite the fact that the solution does not depend only on software changes, but also on behavioral changes in conscientious and responsible use of this feature by different teams, it is worth highlighting that the review of procedures and routines could contribute to a more effective control of costs and losses, with positive effects on patient safety and team work.

[...] it's the pharmacy part [...] sometimes I need 20 diapers for a patient [...] I have to order one at a time, so it takes longer [...] This will result in 20 orders, so it's 20 signatures. I think it should be made easier [...] (Nur. 5). 
Matsuda LM, Évora YDM, Higarashi IH, Gabriel CS, Inoue KC

This statement shows that the system (and the institution) does not accept a stock of materials in the sector. Nevertheless, at least for emergency situations, this difficulty could be solved or at least softened, if workers did electronic records of what has been used. Although the study on the impact on nurses' work, conducted with the help of an electronic monitoring of medicine, ${ }^{22}$ is not directly related to what is being discussed, conclusions regarding the positive aspects observed (better standardization of the process, safety, shorter operationalization time and simplification of documents) can be extended to the scenario in question.

\section{Evaluation of computerization at work}

This theme category appeared from discussions on three sub-themes: satisfaction; staff adaptation; and recommendations for use, which are all related and reflect the way interviewees expressed themselves during the interview: sparkle in their eyes, a sense of pride and satisfaction, because despite pointing some weaknesses in the system, none of the interviewees proved to be indifferent or unhappy with hospital computers and/or software.

[...] this system is very complete, you know? It leaves nothing to be desired [...] it's a very good system (Nur. 1).

I don't hear any complaints from staff. Sometimes there is a computer that is slower than others, but everybody adapted well (Nur. 12).

[...] we have wi-fi here. Many doctors have iPhones, tablets [...]. Some nurses use computers for self-care, to discover pathologies [...] so I learn a lot everyday with the computer (Nur. 10).

It is known that remote access to internet is a particularly easy way to obtain information and news, ${ }^{2}$ and that the use of this feature can close some knowledge gaps and answer nursing care questions.

Regarding the "Recommendations" subtheme, nurses see the importance of technology not only for their work, but also as a trend to be followed by other institutions:

I think it's essential, I would recommend it to other hospitals. Well, I just can't imagine how to work without the computer [...] (Nur. 5).

I think that if other hospitals had the opportunity to have a system like this, it would be a very good thing
[...] it would work very well in other places too (Nur. 3).

I hope that all hospitals be computerized. I think it is better for everyone (Nur. 12).

The systematized functioning and networking of all caregiving processes is an important measure, as real-time access to information surely reduces double work and facilitates decisionmaking.

Although some authors have been reporting for nearly a decade that the concern of nursing regarding IT is focused on language and comprehension of clinical judgment ${ }^{23}$, matters related to the implementation and use of computers by nurses need to be further explored and investigated, in order to enlighten all the possible uses, evaluating the progress and bottlenecks, thus allowing for better decision-making and actions with greater chances of success.

\section{CONCLUSIONS}

Broadly speaking, nurses think that computer use is related to ease, agility and practicality in the execution of professional duties, and is limited by technical and operational aspects. This was observed because the population studied was young and grew up with IT development and dissemination, thus finding it easier to adapt to computer use at work and having greater knowledge of basic editing tools.

The evaluation of computerization at work was mainly influenced by the positive aspects and satisfaction with computer use, having manual recording systems as a reference. In that sense, there were not many nurses who expected improvements in their own computer systems that would facilitate even more the work process; besides, important aspects such as continuous improvement of minimum data summary or use of terminology and/or classification systems to support clinical decision-making were not mentioned.

A limitation of this study was the fact that it was conducted in only one philanthropic hospital, which makes it necessary to deepen the subject in other regions of the country and other health institutions. Therefore, we suggest adopting other study designs, including a quantitative approach, a "before and after" type, so as to compare and measure positive and negative results from IT implementation and achieve continuous improvement of quality and safety of care. 
Finally, computer use, according to the participants of this study, appears to be a tool that organizes, speeds up and humanizes nursing care; but to do so, it is necessary to invest in different resources and raise awareness of professionals regarding the rational and adequate use of this tool.

\section{REFERENCES}

1. Hannah KJ, Ball MJ, Edwards MJA. Introdução à informática em enfermagem. $3^{\mathrm{a}} \mathrm{ed}$. Porto Alegre (RS): Artmed; 2009.

2. Duplaga M, Andrychiewicz A, Danda J. The opinions about e-health among nurses employed in hospitals located in an urban area in Poland. Comput Inform Nurs. 2013 Jun; 31(6):281-9.

3. Takhti HK, Rahman AA, Abedini S, Abedini S. Impact of hospital information system on patient care: nurses' perceptions. Cann J Nurs Inform [online]. 2012 [acesso 2013 Jul 05]; 6(4). Disponível em: http:/ / goo.gl/1ZZyNI

4. Sousa PAF, Sasso GTMD, Barra DCC. Contributions of the electronic health records to the safety of intensive care unit patients: an integrative review. Texto Contexto Enferm [online]. 2012 [acesso 2013 Jul 08]; 21(4):971-9. Disponível em: http://goo. gl/0VU84Q

5. Bassendowski S, Petrucka P, Breitkreuz L, Partyka JM, Dougall LM, Hanson B, et al. Integration of technology to support nursing practice: a Saskatchewan initiative. J Nurs Inform [online]. 2011 [acesso 2013 Mar 10]; 15(2):635. Disponível em: http://goo.gl/sk0gS9

6. Seidlitz W, Blatz S, Jennings B, La Rocca R. Eletronic health records in my unit? No thanks! A qualitative research project using extreme case sampling. Can J Nurs Inform [online]. 2013[acess 2013 Jul 05]; 7(3\&4). Available in: http:/ / goo.gl/QBwK72

7. Fonseca LF, Brennan PF. Computerized decision support system and decision quality of nurses. Cienc Cuid Saude [online]. 2012; 11(suplem.): 26773 [acesso 2013 Apr 10]. Disponível em: http:/ / goo. $\mathrm{gl} / \mathrm{ry} 2 \mathrm{sLG}$

8. Abbass I, Helton J, Mhatre S, Sansgiry SS. Impact of electronic health records on nurses' productivity. Comput Inform Nurs. 2012 May; 30(5):237-41.

9. Bardin L. Análise de conteúdo. Lisboa (PT): Edições 70; 2011.

10. Dellinger RP, Levy MM, Rhodes A, Annane D, Gerlach H, Opal SM, et al. Surviving sepsis campaign: international guidelines for management of severe sepsis and septic shock: 2012. Crit Care Med. 2013 Feb; 41(2):580-637.

11. Agência Nacional de Vigilância Sanitária (BR) [página na internet]. Série Segurança do Paciente e Qualidade em Serviços de Saúde. Investigação de Eventos Adversos em Serviços de Saúde. 2013. [acesso 2013 Jul 20]. Disponível em: http://goo. $\mathrm{gl} / 3 \mathrm{~V} 90 \mathrm{Oc}$

12. Keers RN, Williams SD, Cooke J, Ashcroft DM. Causes of medication administration erros in hospitals: a systematic review of quantitative and qualitative evidence. Drug Saf. 2013 Nov; 36(11):1045-67.

13. Radley DC, Wasserman MR, Olsho LEW, Shoemaker SJ, Spranca MD, Bradshaw B. Reduction in medication errors in hospitals due to adoption of computerized provider order entry systems. J Am Med Inform Assoc [online]. 2013 [acesso 2013 Set 10]; 20:470-6. Disponível em: http:/ / goo.gl/SqHxiB

14. Rodriguez-Gonzalez CG, Herranz-Alonso A, Martin-Barbero ML, Duran-Garcia E, DurangoLimarquez MI, Hernández-Sampelayo $\mathrm{P}$, et al. Prevalence of medication administration error in two medical units with automated prescription and dispensing. J Am Med Inform Assoc [online]. 2012 [acesso 2013 Set 10]; 19:72-8. Disponível em: http:// jamia.bmj.com/content/19/1/72.full.pdf + html

15. Correia MJA, Diogo RCS. Avaliação da informatização de UTI por enfermeiros em relação aos cuidados de enfermagem. J Health Inform [online]. 2012 [acesso 2013 Set 10]; 4(Esp):195-9. Disponível em: http://www.jhi-sbis.saude.ws/ ojs-jhi/index.php/jhi-sbis/article/view/251/147

16. Chow SKY, Chin WY, Lee HY, Leung HC, Tang FH. Nurse's perceptions and attitudes towards computerization in a private hospital. J Clin Nurs. 2012 Jun; 21(11-12):1685-96.

17. Azevedo LMN, Oliveira AG, Malveira FAS, Valença $\mathrm{CN}$, Costa EO, Germano RM. A visão da equipe de enfermagem sobre seus registros. Rev Rene. 2012; 13(1):64-73.

18. Conselho Federal de Medicina [página na internet]. Resolução CFM n. 1931/2009. Brasília (DF): Diário Oficial da União; 2009. Seção I, p. 173. [acesso em 2013 Jul 18]. Disponível em: http:/ / goo.gl/vI8tX

19. Conselho Federal de Enfermagem. Resolução COFEN n. 311/2007. Rio de Janeiro (RJ): COFEN; 2007.

20. Conselho Regional de Enfermagem de São Paulo [página na internet]. Anotações de enfermagem. São Paulo (SP); 2009 [acesso 2014 Jan 13]. Disponível em: http://goo.gl/3U3Sw

21. Silva LA, Secco IAO, Dalri RCMB, Araújo AS, Romano CC, Silveira SE. Enfermagem do trabalho e ergonomia: prevenção de agravos à saúde. 2011. Rev Enferm UERJ. 2011; 19(2):317-23.

22. Callen J, Hordern A, Gibson K, Li L, Hains IM, Westbrook JI. Can technology change the work of nurse? Evaluation of a drug monitoring system ambulatory chronic disease patients. Int J Med Inform. 2013; 82(3):159-67. 
23. Évora YDM, Melo MRAC, Nakao JRS. O desenvolvimento da informática em enfermagem: um panorama histórico. Anais do IX Congresso Brasileiro de Informática em Saúde, 2004 Nov 07-10;
Ribeirão Preto, Brasil. Ribeirão Preto (SP): SBIS; 2004. Sessão Oral SO\#27. [acesso 2013 Jun 15]. Disponível em: http:/ /goo.gl/exUlju 